Human Ethology Bulletin - Proc. of the V. ISHE Summer Institute (2016): 30-46

Theoretical Review

\title{
UNIVERSALS IN RITUALIZED GENITAL DISPLAY OF Apotropaic FeMALE Figures
}

\section{Christa Sütterlin}

Human Ethology Group, Max-Planck Institute for Ornithology, Seewiesen, Germany.

suetter@orn.mpg.de

\begin{abstract}
Human genital display as part of the sculptural repertoire was presented and discussed within a wider ethological framework in the sixties of the last century. Male phallic display is widely referred to as a rank demonstration and ritualized threat rooted in male sexual behavior, and it is discussed as a symbolic dominance display and defense in the artistic context as well. Female sexual display in sculptures, however, is prevalently interpreted in terms of erotic and fertility aspects in art literature. Ethologically it is described as a gesture with at least ambivalent meaning. A recent analysis of its artistic presentation in the nineties of the last century has given rise to a new discussion of its function and meaning, on the behavioral as well as on the sculptural level. Crosscultural consistency, functional context and expressive cues thereby play a primary role in this regard. In addition, a new consideration of behavioral relicts contributes to reinterpreting the gesture, both ethologically and artistically. The concept of ritualization may be of particular help for a better understanding of its archaic behavioral background and its special relevance for the arts. The sculptural motive is in the meantime partially accepted as an "apotropaic" (aversive) motive even in archaeological circles, but any derivation from behavioral origins is still far away from being integrated.
\end{abstract}

Keywords: Female genital display, ethology, ritualization, art, and cultural comparison. 
Sütterlin, Ch.: Universals in Ritualized Genital Display of Apotropaic Female Figures

Human Ethology Bulletin - Proc. of the V. ISHE Summer Institute (2016): 30-46

\section{INTRODUCTION}

Humans not only leave their traces in material relics such as bones, cloths or reported behavior, but also in cultural artifacts. These include traces of human beliefs, ideas, and perceptions. Earliest engravings - for instance regular parallel lines incised on a tibia bone by Homo erectus - make clear that artifacts represent more than a replica of the environment, but rather a sort of concept of this world and a way to symbolically communicate it. Human artifacts can tell us more about the artist and his cultural readings of a subject than about the portrayed subject itself. Art does not present realities but instead construed realities, and this makes art revealing for any sort of science, cultural as well as natural. A anthropology of the arts from an evolutionary perspective (Dissanayake, 1992, Dutton, 2009 , Eibl-Eibesfeldt \& Sütterlin, 2008, Sütterlin, Schiefenhövel et al. 2014) opens new fields of questions and answers regarding the emotional, behavioral, cognitive and adaptive cultural spectrum of humans.

\section{ARTISTIC MATERIALS: SITES AND EXAMPLES}

The evidence of female representations with distinct genital display was for a long time not a reason for any particular iconographical inquiry. The figures appeared in the architectural context of Romanesque churches and sanctuaries and were mostly subsumed under the headings of grotesques and exoticism (Sheridan \& Ross, 1975). This was one method to exclude them from the canon of holy figures. In some cases their integration into the system of Christian iconography could match the concept of the "Sins and Vices", for which a place was reserved at times within the pictorial program of a church. The sculptures then stood for the representation of "Luxuria", a woman with all the gestures and positions of female seduction. But often the figures turned out to be spolia, i.e. sculptural remains from an older building. Then their interpretation would be turned toward "archaism" or was left to ethnographers and folklorists. This proved to be the better approach, since it included the comparison of wider historical and geographical fields.

As the arguments of exoticism as well as of grotesques were handy substitutes to consign the inconvenient subjects to the idea of artistic freedom, the range of randomness in their appearance was never scrutinized. In fact, their display format shows a quite rigid formal grammar. In most of the cases the figures represent a squatting woman, with spread legs and a clearly exposed vulva. In some sculptures one or even two hands decisively support the exposition.

Representations are found in vast numbers in England, Ireland and France, to a smaller extent in Germany and the rest of Europe (see Fig. 1). In the English and Irish vernacular they are called "Sheela" (Andersen, 1977), referring to a powerful woman or hag.

If the erotic appeal is still resonating in many of the publications on the subject, the aspect appears counteracted by contextual traits, such as the physiognomy and even the mimics of the figures. The features are mostly dreadful and repelling, the mimics threatening and do 
therefore not match, or allude to, an erotic invitation. Another feature is the strict frontality. None of the figures is shown to be involved in an erotic interaction, but is instead isolated from other figures. The appearance rather follows the folkloristic Irish tales of women called "Shila na Gig" who were secretly visited by men who felt burdened by "ill luck". In this context the gesture of genital display was ritually performed against the evil eye (Kohl, 1843, p. 207).

From an art historian's view one could proceed by comparing and analyzing different appearances of the motive at that time in a defined geographical area. This would certainly lead to a valid typography, consistent with local semantics. In fact such inquiries do exist (Andersen, 1977; Ross, 1973) - but then, how should one approach figures of a similar typology in Africa, Indonesia, South America and Melanesia?
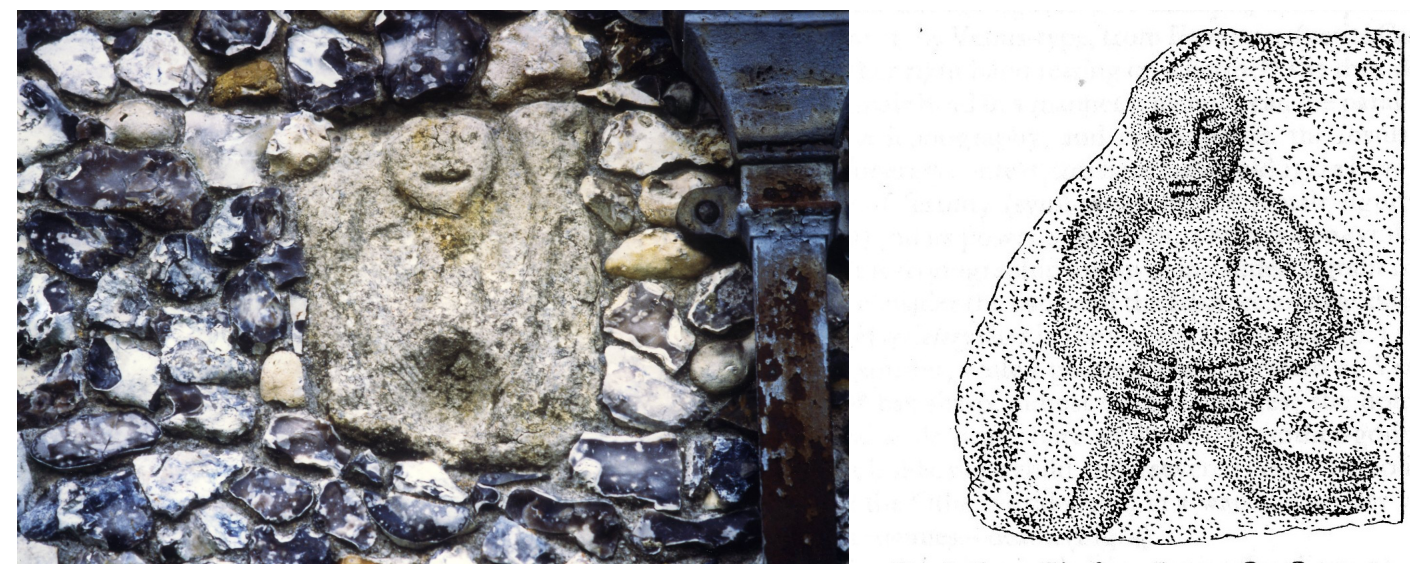

Figure 1. Left: Sheela from the south wall of Buckland Parish Church, Buckinghamshire. 12th century. Photo: Eibl-Eibesfeldt; Right: Sheela from Lavey Church (Co.Cavan, Ireland). After A. Ross (1973) p. 147

\section{THE ROLE OF CULTURAL COMPARISONS IN SEARCH OF CULTURAL UNIVERSALS}

Magical figures in Africa often show the genital display both in the male and the female version. The exposition may occur in a more decent gesturing, such as in figures of the Fang (Cameroon), the Dengese (Congo) or Senufo (Ivory Coast) (see Fig. 2 and Fig. 3). Both hands are set aside the vulva in a hinting manner. Nayarit figurines from West Mexico and grave figures from Nicaragua also show a clear but well marked exposition of the genital parts (Willey, 1985, XI). The mimics are mostly firm and rigid. More expressive the figures from Indonesia and Melanesia: The legs are spread widely apart, the hands involved in the displaying gesture and the mimics highly vigorous, like in the figure from Lembata Island (Indonesia) and female figures from suspension hooks and entrances in the Sepik, Papua New Guinea (see Fig. 4 and Fig. 5). The latter are called "Dilukai", are monumental in size, and known as powerful protection symbols of prominent places (Eibl-Eibesfeldt \& Sütterlin 
1992, figs. 120 a-c). The Hampatong, wooden protective ancestor figures of Borneo, preferably show the male genital display, but in the Akha woodcarvings of Northern Thailand the female gesture is pronounced. The tall figures are placed before the entrance of the village, stand upright and hint at their genitals (Leuzinger, fig. 301a). Fertility aspects are discussed but at last dismissed - the figures are meant to keep away hostile persons and spirits (Young, 1974; Goodman, 1996). Legion are the examples of smaller figurines with the exposing gesture, used in funerals and other magical rituals.

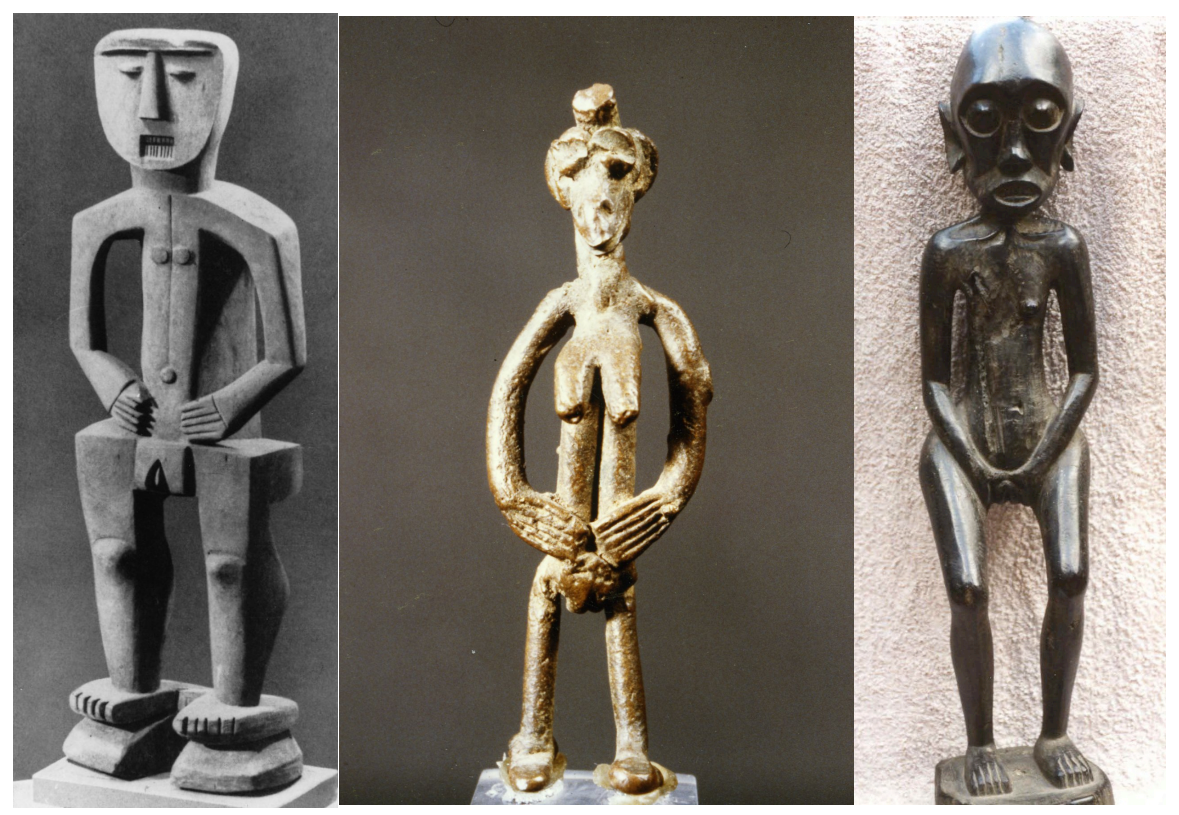

Figure 2. (left): Female figure of the Fang (Cameroon), hinting at the genital region. Photo: Kirchenberger.

Figure 3. (center): Yellow cast figurine $(6.4 \mathrm{~cm})$ used for magic among the Senufo, Ivory Coast. Photo: Gottschalk.

Figure 4 (right): Figure of a spiritual healing hag from Lembata (Indonesia). Photo: Ramseyer.

Cultural comparison is a fascinating field, especially in art. Similarities can arise on the basis of cultural exchange (diffusionism) or independent emergences (convergence).

While the issue of cultural information transfer is most of all the subject of art historians, cultural universals or convergences are studied preferably by human ethologists. In the latter case it should be noted that similarities per se are not a sufficient argument. They could be the effect of imitation and information transfer (see above), especially later in history, when migration was made easier. Therefore, the study of prehistoric art and comparison of examples from far-off cultures, as presented here, has become the kings-road of inquiry in the search for universals. 


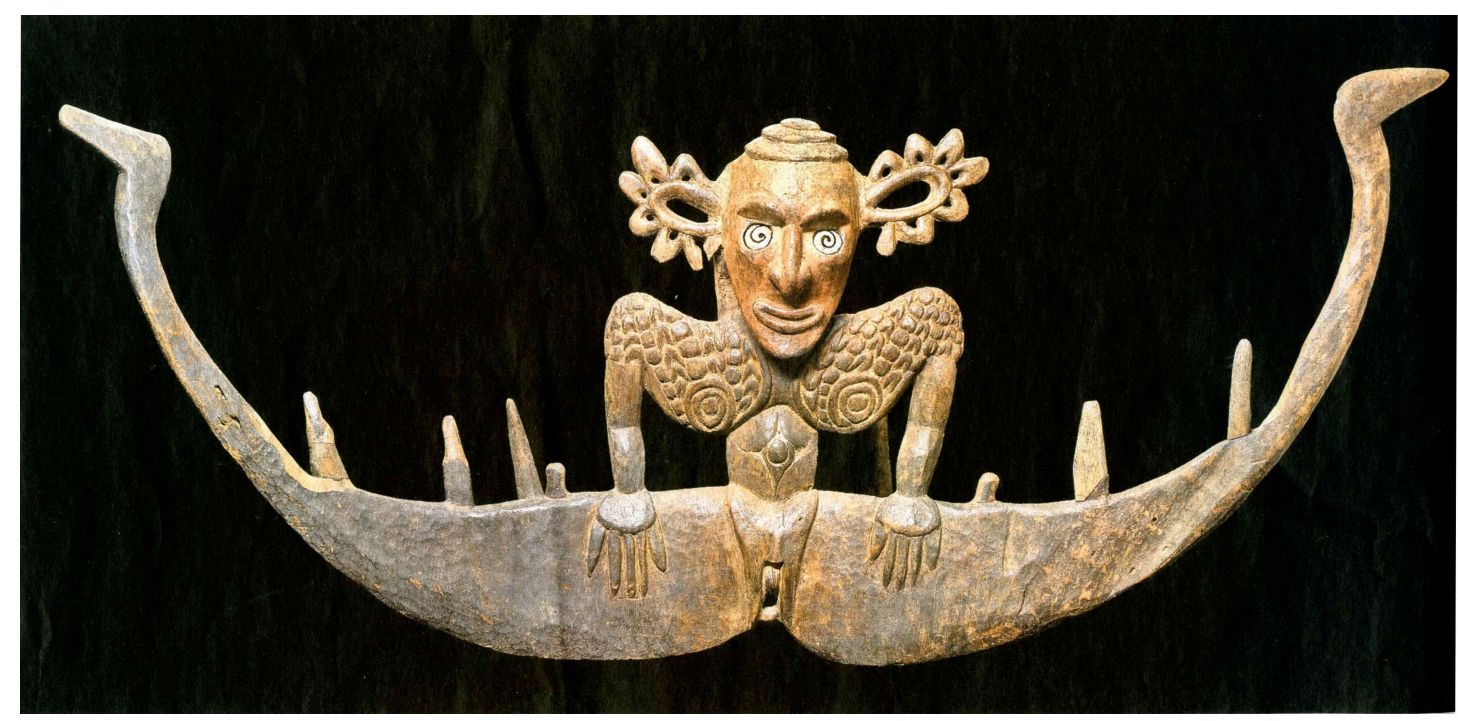

Figure 5. Female figure-hook, wood, nacre and fibers $(73 \times 166 \times 45 \mathrm{~cm})$, from Yentchanmangua village (Iatmul group), collection Adolf Roesicke 1912 from Kaiserin-Augusta-Fluss-Expedition. Anthropological Museum Berlin (Inv. Nr. 54998).

Neolithic representations of female exposing figures are known from Rock engravings in the Fezzan (Libya), from Sumerian seals (see Fig. 6), figures of the Hamangia culture (Ceamurilia de Jos, Romania), idols from South-Iran, reliefs from Catal Höyük and smaller female idols from Anatolia (Charrière, 1970, Devereux, 1981, Mellink \& Filip,1985). Several Neolithic funeral stelae with the hands on the genital region were found in Upper Italy (Anati 1981). The Lepenski Vir figure (Serbia) is still under discussion (Eibl-Eibesfeldt \& Sütterlin 1992, 11f). Most monumental and striking are the Fezzan examples (see Fig. 7). Although introduced as erotic representations by Charrière (1970), the figures presented here are rendered in strict frontality, directed towards the visitor. The men wear headcoverings as documented in ritual scenes. The women also wear a headpiece.

The co-aspect of mimic expression in prehistoric examples is rather hard to evaluate since the faces are generally veiled or sparsely defined (Sütterlin, 2013). In the so-called "Nude Goddesses" of Northern Karnataka (India), female votive figures that represent an indigenous replica of the Ishtar motive, a head is mostly lacking (see Fig. 8). But the Lepenski Vir figure I rate among the prominent Neolithic examples, shows a decisively dreadful face and repulsive expression comparable to the Sheelas in later medieval England and Ireland. And examples from Megalithic Indonesia display the gesture in combination with a terrorizing facial expression, bared teeth and pronounced staring eyes (see Fig. 9). In the Oceanic art region the repellent threat face belongs to the usual repertoire of demonstrating female ancestral figures from the Sepik as well as to guardian figures from Bali and Timor, protecting house and garden (see Fig. 10), and the healing hag of Lembata Island (see Fig. 4). 


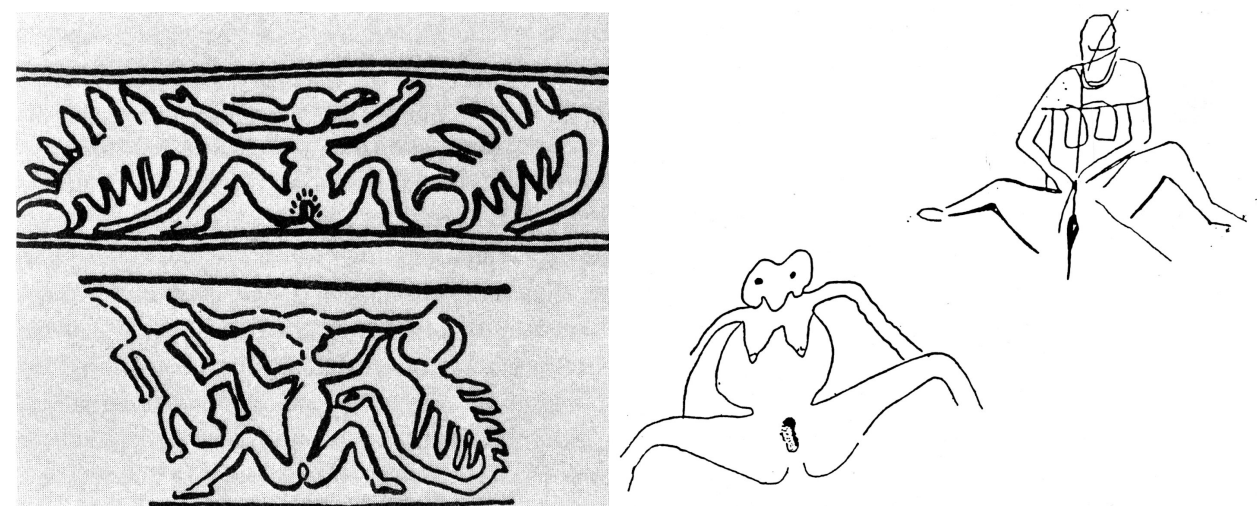

Figure 6. (left): Female exposing representation (called Ishtar) in Sumerian seals (3rd millennium B.C.). After Devereux 1981, fig. 4.

Figure 7. (right): Rock engravings from Fezzan (Libya) at left, and Tassili n'Ajjer (South Algeria), at right. $7000-5000$ B.C. From Charrière 1970 fig. 2.

Furthermore, the mimic accessories are linked to another criterion that seems to prevail with regard to an independent evolution of the motive in the cross-cultural perspective: the functional aspect. And this aspect matches the criterion of analogy as one way of defining cultural similarities as well (Eibl-Eibesfeldt, 2004, p. 201). The function can be defined as apotropaic in the sense of magical protection and amuletic support. It can usually be derived from the place the objects are attached or to which larger context they belong. Grave figures and ancestor figures are traditionally attributed to rituals invoking spirits needing to be appeased or counteracted. Sanctuaries and their fields, burial sites, are the customary places of topological taboos. This also applies to churches. Only after the verdict of Saint Bernard in the $12^{\text {th }}$ century were all the non-Christian disconcerting symbols removed and forbidden.

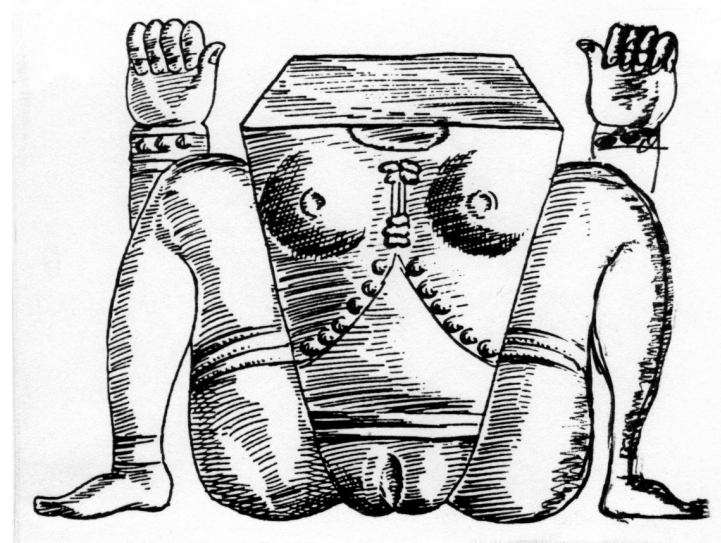

Figure 8. „Nude Goddess” or so-called "Shameless Woman” from a cave painting in Siddan Kotte (Northern Karnataka India), $2^{\text {nd }}$ century A.D. From Sankalia 1960, fig. 6. 


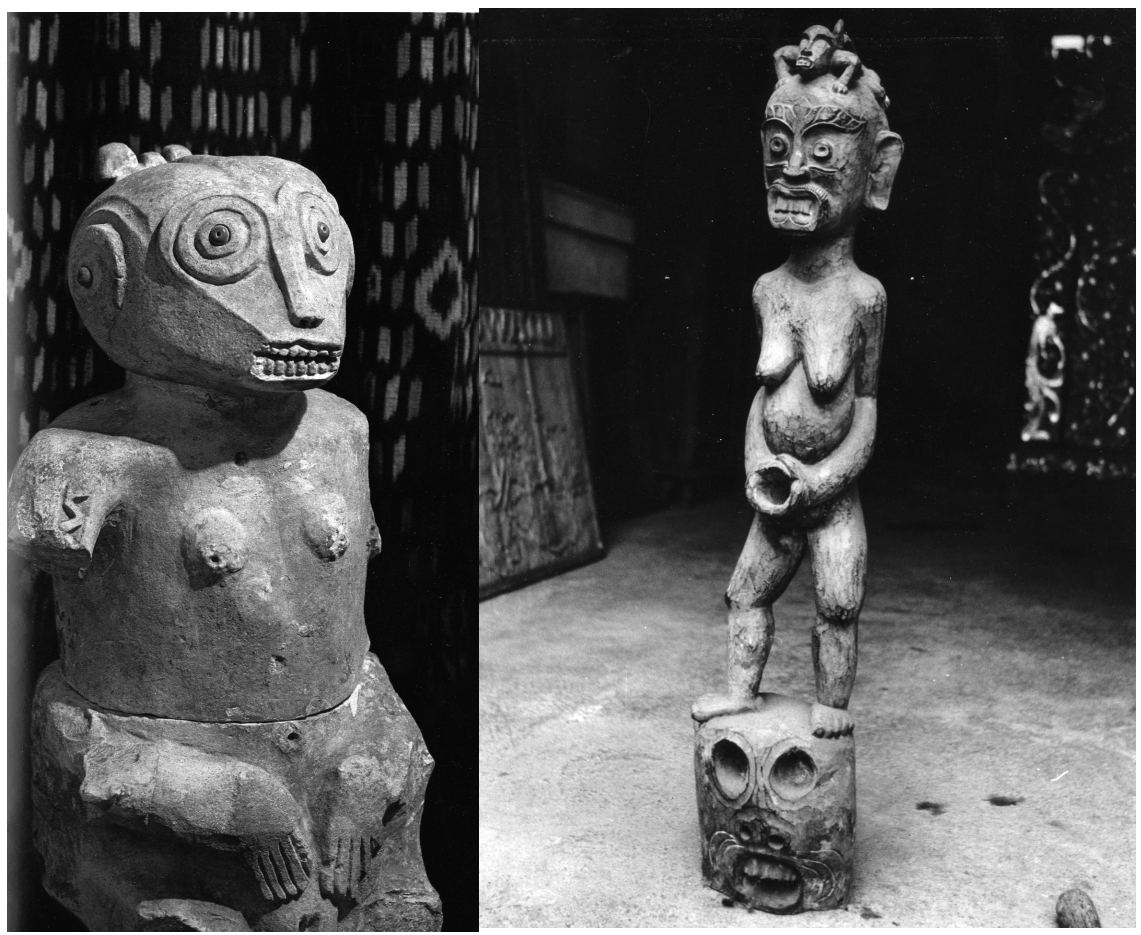

Figure 9. (left): Megalithic figure with genital and teeth display from Laoli, Sunda Islands (Indonesia), 3000-1000 B.C. Photo: Ramseyer.

Figure 10. (right): Female guardian figure with genital and teeth display from Timor (Indonesia). Photo: Eibl-Eibesfeldt.

The most evident section of objects linked to the averting function, in particular amulets, includes the gesture at least since antiquity. While amulets with the male symbol, often in the form of a small replica of the organ, are a more popular version, the female equivalent, more decently codified, often shows a squatting woman hinting at her pudenda (Hauschild, 1984) (see Fig. 11a). Amulets of modern Japan combine both versions up to the present day (Eibl-Eibesfeldt 1970) (see Fig. 11b). The Roman motive seems to have a long tradition in the Mediterranean area, joining into the pictorial formula of the Gorgo-Medusa as the classical apotropaic archetype of Ancient Greece (Hansmann \& Kriss-Rettenbeck, 1966; Hauschild, 1984). The Gorgoneion, meaning the Gorgon's head with protruded tongue and bared teeth, was a motive present on warrior shields, chariots, temples as well as on objects of ritual and even profane use - for the deterrence of evil influences, intruders and enemies. In the full representation, the Gorgon appeared as a squatting monster showing her denuded pudenda in combination with her fear-inspiring face. Goldman (1961) and Devereux $(1981,60)$, like many others, see the ancestry of the Gorgon in a manifold Asiatic tradition, as manifest in the figures of Baubo, in the Nude Goddess of India, the Mistress of the Animals in the Luristan Bronzes, Sumerian Lamashtu and Ishtar on the Babylonian seals (Fraser, 1966; Gsell, 2001; Przyluski, 1950; Sankalia, 1960). 


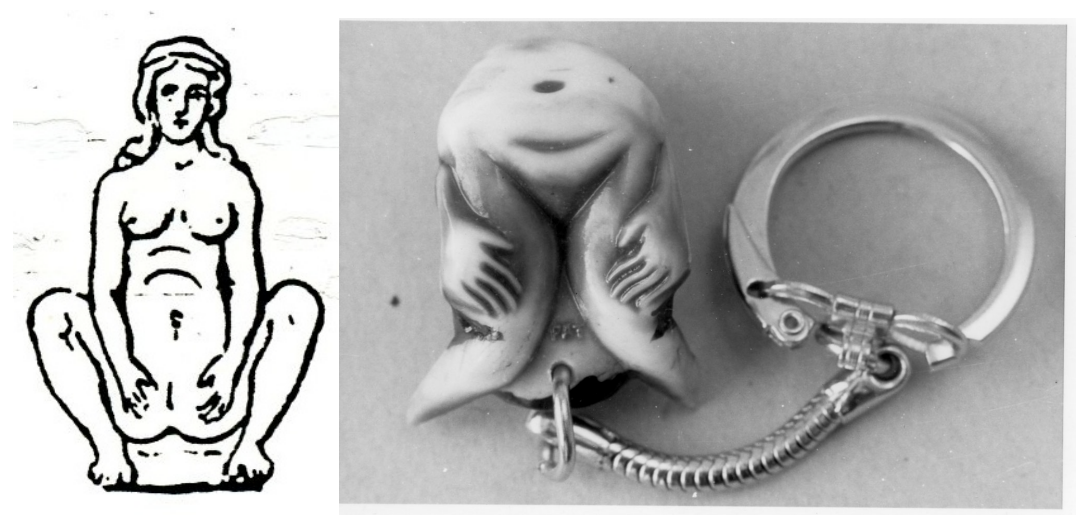

Figure 11a. (left): Amulet to ward off the evil eye from Ancient Rome. After Hauschild 1984, fig. 4.

Figure 11b. (right): Amulet in the form of a key-pendant in modern Japan. Photo: Eibl-Eibesfeldt.

Fertility and erotic aspects are, amongst others, discussed by Charrière (1970), Conteneau (1914) and Murray (1934), but all of them struggle with arguments against the visual aspects of facial disfigurement. Conteneau cites the ambivalent character of Isthar as a fecundity-goddess and war-mistress; Murray splits the aspects into Great Mother (IsisDemeter), Divine Woman (Ishtar) and the Baubo-type of the sexually exposing woman, while Przyluski (1950) emphasizes the hermaphrodite character of the ancient female goddess. Only Fraser (1966), Goldman (1961) and Hauschild (1984) insist on the violent aspect of the figure:

"She is savage, she is violent, she is the goddess. She is awful and she is like a leopard (...). She attacks the womb of the pregnant. She snatches the babe from the nurses. Great are her weapons. Her head is that of a lion, her teeth of an ass, her lips are a spray, pouring out vomit." (Goldman, 1961, pp. 6-7)

This does not sound like the description of a benevolent fertility goddess, but visualizes the features of a powerful demon fighting against demon spirits in equal measure. Even Baubo, in some representations pictured as a laughing goddess on a pig, is shown with a grimacing face, the mouth pulled apart (Kirchhoff, 1984; Schefold, 1954, p. 218).

If cross-cultural similarities of a complex pictorial formula include similar functions and even literary semantics over a longer period, we speak of a cultural universal. Moreover, the linkage of the highly consistent mise-en-scène of the gesture to concepts of defense and power raises questions of how such a universal understanding came about. The effort of an answer cannot avoid the issue of signalism in human visual communication (Eibl-Eibesfeldt \& Sütterlin, 1992, p. 55f). Notions of power may vary culturally in myths and personifications over time, but their pictorial presentation provides evidence of a remarkably conservative formula. 
What kind of impact can we expect from these surprisingly widespread cultural aspects on an ethological reconsideration of the female gesture? Are such clearly violent modulations of the artistic subject apt to parallel any behavioral evidences?

\section{ROOTS AND REPORTS OF BEHAVIOR}

Phallic display in ethology is referred to as a male rank demonstration and ritualized threat rooted in male sexual behavior of mammals and primates (Ploog et al., 1963; Wickler, 1966). In the meantime it is also widely being discussed as a dominance display in humans and a symbolic defense in sculptural representations as well (Eibl-Eibesfeldt, 1970; EiblEibesfeldt \& Wickler, 1968; Eibl-Eibesfeldt \& Sütterlin, 1992; Vanggard, 1971; Wickler, 1967). Female sexual display in sculptures, on the other hand, is still prevalently interpreted by means of erotic and fertility aspects. Ehologically it is described as a gesture with at least an ambivalent meaning and intent.

Submissive aspects of female genital display can be derived from sexual presenting in females observed in different primates like the bonobos, vervet monkeys etc. (Wickler, 1967). As sexual presenting is not exclusively connected with sexually motivated activities, but provides also social appeasing effects, Wickler talks about socio-sexual signals. Evidently male individuals also present their behind toward higher-ranking males. In general, presentation seems to occur more frequently in social than in sexual situations. Sexual presenting as a social greeting ceremony is again described between both sexes by Wickler, $(1967,79,86)$. On the other hand, female sexual behavior is also observed in contexts of social rank. Several reports confirm higher aggressiveness of females in heat, for instance in rhesus monkeys. They also start to approach males and often cross group boundaries (Rowell, 1963). Receptive female chimpanzees present their backside without signs of submission or fear (Reynolds \& Reynolds, 1965). The behavior could be described at least as sexually and socially provocative.

So far, sexual presentation in animals is performed 'a tergo'. This coincides with the male behavior of mounting. The frontal presentation seems to be an exclusively human performance - and obviously not related to a direct male sexual behavior. Evidently it is meant as a signaling or expressive behavior in the context of nonverbal communication. Sexual invitation may be one message to be observed in respective social circles. In the Kalahari San Eibl-Eibesfeldt documented the behavior in mocking girls who exposed their genitals towards the author upon filming. As he was recording with a mirror lens, the camera was turned away at a $45^{\circ}$ angle and the girls believed themselves unobserved. They laughed and made funny faces, also imitating his filming behavior (Eibl-Eibesfeldt, 1972, p. 130)(see Fig. 12). This rather refers to a provocative behavior on more aggressive grounds. Another report cites a three-year-old naked girl in Germany who performed a whole sequence of genital displays from the front and 'a tergo' in front of visitors after an admonishment by her father to put some clothes on (Schiefenhövel, oral communication). This was evidently 
meant as a protest and includes an understanding of the gesture as being socially not tolerated.

Historical sources give similar evidence: We know the report of Plutarch about Lycian women who exposed their genitals against the intruder Bellerophontes as well as against rising storms (Reinach, 1912: 117). Pliny the Elder in the first century A.D. reports a similar gestural magic in his Natural History (Plinius Sec., 1983), and it does not amaze to read about such tales in Celtic Ireland (Reinach, 1912: 117f). Deonna (1917) even cites a chronicle from old Geneva, Switzerland, about the defense of the town under siege in $16^{\text {th }}$ century. There, women were advised to appear on top of the town wall, shouting humiliating words and showing their pudenda to the enemy. Finally, "Anasyrma" is the name of a cultic gesture in ancient Greece, in the course of which women ritually exposed their genitals to scare-off hostile influences (Reinach, 1912, 117).

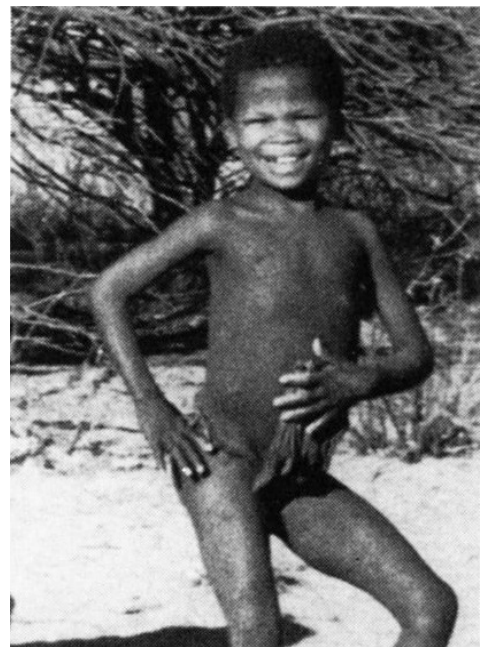

Figure 12.: Mocking !Ko-San girl lifting her small apron in a presenting attitude towards the author filming with a mirror lense. From a $16 \mathrm{~mm}$ film by I.Eibl-Eibesfeldt.

Evidently, comparably to the male sexual display, the gesture proves to have emancipated from its sexual appeal into a ritualized expressive movement or signal of dominance display (Eibl-Eibesfeldt \& Sütterlin, 1992: 235, 243). The historical reports confirm a semantics that is sexually independent. The origins of the gesture, the hint to the sexual and reproductive organs, however, do not appear as arbitrary. Reproductive success is and remains a manifestation of physical health and power. The relevance of good luck and happiness would be another reading with which bad influences could be deterred. For the most the pictorial representations hold to the rigid and aggressive version of a more or less exorcistic and magic instrument. The mimics of protruding tongue and bared teeth, often combined with the gesture, give further evidence of a clustered meaning of aggressive refusal, derision and disgust, which form an irresistible compound of virtues. As Anne Ross puts it in her publication on the "Divine Hags of the Pagan Celts" (1978): 
"I would like to suggest that, in their earliest iconographic form, they do in fact portray the territorial or war-goddess in her hag-like aspect, with all the strongly sexual characteristics which accompany this guise in the tales; and that they are not 'pornographic' or 'erotic' monuments but have both a fertility and an evilaverting significance. [note: It is a known and widespread belief that to expose the genitalia of either sex acts as a powerful apotropaic gesture]. This would serve to explain why they are frequently to be found in association with Christian churches. Such figures could hardly have been built into religious buildings of the post-pagan period unless it was to canalize the evil-averting powers they were believed to possess" (148-149).

Meanwhile the apotropaic character is accepted even in archaeological circles (Qasim, 2009; Schmidt, 2013, 199).

A more recent ethnographical commentary strongly confirms the historical reports regarding social context and effect: Schieffelin \& Crittenden (1991) refer to an occurrence during the expedition realized by Jack Hides and James O'Malley in 1935 to the Great Papua Plateau. In the different first contacts the two patrol officers were confronted with rigid violence and low acceptance. Especially in the Waga valley (highlands) the atmosphere was hostile and frosty. The men stood in a pile, and from another side forty women were introduced. The visitors first hoped for an appeasing moment in the interaction. But the women sat down in a row in front of the men and simultaneously lifted their skirts, displaying their pudenda and shouted with extreme violence: "Hides was quite taken aback and mystified at this surprising act. He did not know they were treating him as malevolent supernatural being and were trying to defuse his power and chase him away." (p.140). One needs to know that the vulva is described as a powerful organ among the Eipo (West New Guinea) and tabooed in many ways. No man would sit where a woman had sat before him (Koenig, 1975, 370f; Schiefenhövel, oral communication).

\section{ARTISTIC MODIFICATIONS OF RITUALIZATION}

It has become clear from the different documentations that the gesture was not part of a customary female behavior, but rather a discrete, highly ritualized and culturally codified gesture already in its natural occurrence. Evidently it has become a signal with a specific meaning. The same is certainly true for its sculptural representation. The adamant relation between the semantics of an Apotropaion and its artistic formulation is a striking fact. Douglas Fraser (1966), giving an exuberant example of the cross-cultural consistency and continuity of the pictorial formula in his famous article on the Heraldic Woman, builds on the schema of the woman with her legs spread between two flanking wild animals, first described in the motive on Luristan pins of ancient Iran (see Fig. 13). The iconographic formula present in many representations of the Etruscan Gorgon holds true up to recent representations in traditional cultures worldwide. Fraser, giving examples from Africa, 
Indonesia, the Sepik and the Solomon Islands, still defends the diffusionist approach to cross-cultural similarities, i.e. the explanation model of one figuration spread by imitation and cultural exchange. But as cultures usually modify whatever can be modified, the persistency of such formulas stimulates questions. Again, no culture is obliged to borrow a motive from another culture unless its figuration is convincing. And no culture is forced to implement whole and complex iconographies into its own pictorial repertoire under the same meaning and function. Above all, no motive is forced to become a stringent heraldic formula with an expansion of intercultural dimensions.

One further artistic modification of the motive could be the one of the "Siren" present in the ornamental repertoire of many cultures. The Siren is a mythical but formally stylized motive of a spreading woman in the form of a mermaid. Its affinity to the old motive of the displaying woman is evident in the occasionally marked vulva such as in the Sirens of Avila, Spain (see Fig. 14), or on the door of St. Jakob, Regensburg, Germany. Its archaic aspect is softened by the attributes of long hair and a neutral face (Sütterlin, 2000). The fluent transitions from figures of the spreading displaying woman can be seen in the examples of Papua New Guinea (see Fig. 5).
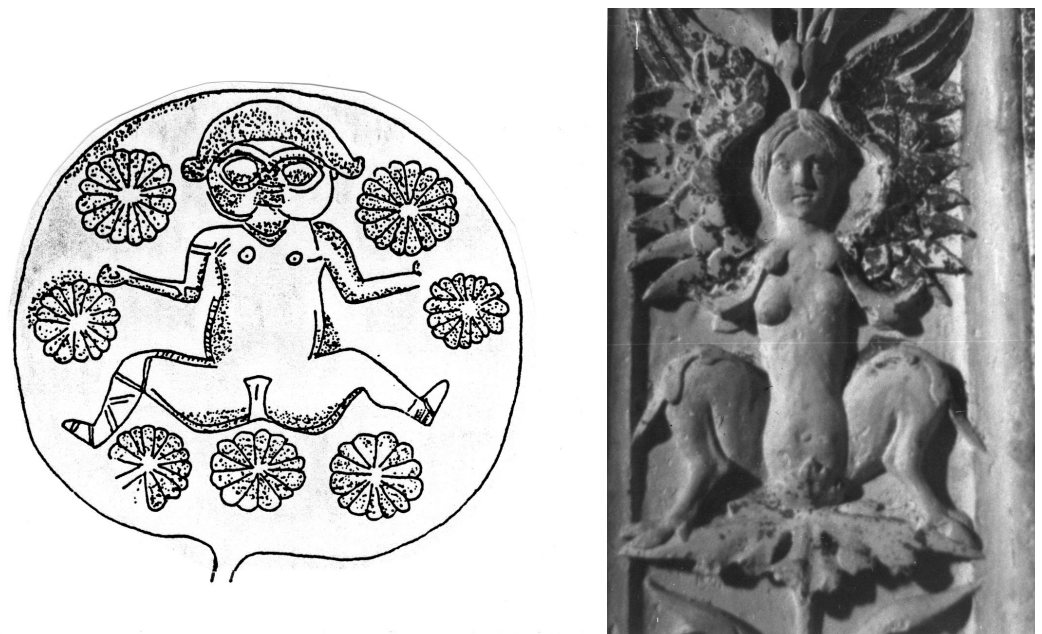

Figure 13. (left): Votive pin (bronze) from Luristan (ancient Iran). 700 B.C. Charrière,1970, 149. Figure 14. (right): Siren from Avila Cathedral (Spain) $\left(12^{\text {th }}\right.$ century). Photo: Sütterlin

\section{GESTURAL SIGNALING AS A FURTHER RITUALIZATION IN THE VISUAL ARTS}

A gesture in this context, presented here for the first time, had a similar career of distribution but received no real attention. In the Buckland- and Ballyportry-"Sheela" (see Fig 1), the hands of the figures are directed distinctly towards the genital region, in the latter example even grasping the lip of the organ. In the African figures of the Fang, Cameroon, and the Senufo, Ivory Coast (see Fig. 2 and Fig. 3) both hands point to the female organ. Very 
similarly the gesture is seen in various female so-called ancestor figures in Melanesia and Oceania (see Fig. 15). The figures represent spirits that in the ethnic thinking are indispensable and vital for the group's survival. It is a noticeable gesture: symmetrical, stylized, paralleled and oriented towards the organ it evidently aims to hint at. It even can be called an intentional gesture, highlighted by distinct and even prolonged or colored fingers. They often become an optical signal per se. In the Moai figures of the Naunau Group of Anakena, Easter Island, the fingers make clear that the figures were hinting at their genitals (see Fig. 16) - a fact which is underpinned by a range of smaller wooden figures of the region that expose their extremely marked genitals. The examples mirror the facial type and expression of the colossal Naunau figures and form female counterparts to the Moai Kavakava, typically frightening male figures with staring inlaid eyes and bared teeth. Male or female, the figures show the same display. The Megalithic culture has been estimated at an age of about 1500 years, and the tradition of the smaller figures is a highly persisting one.

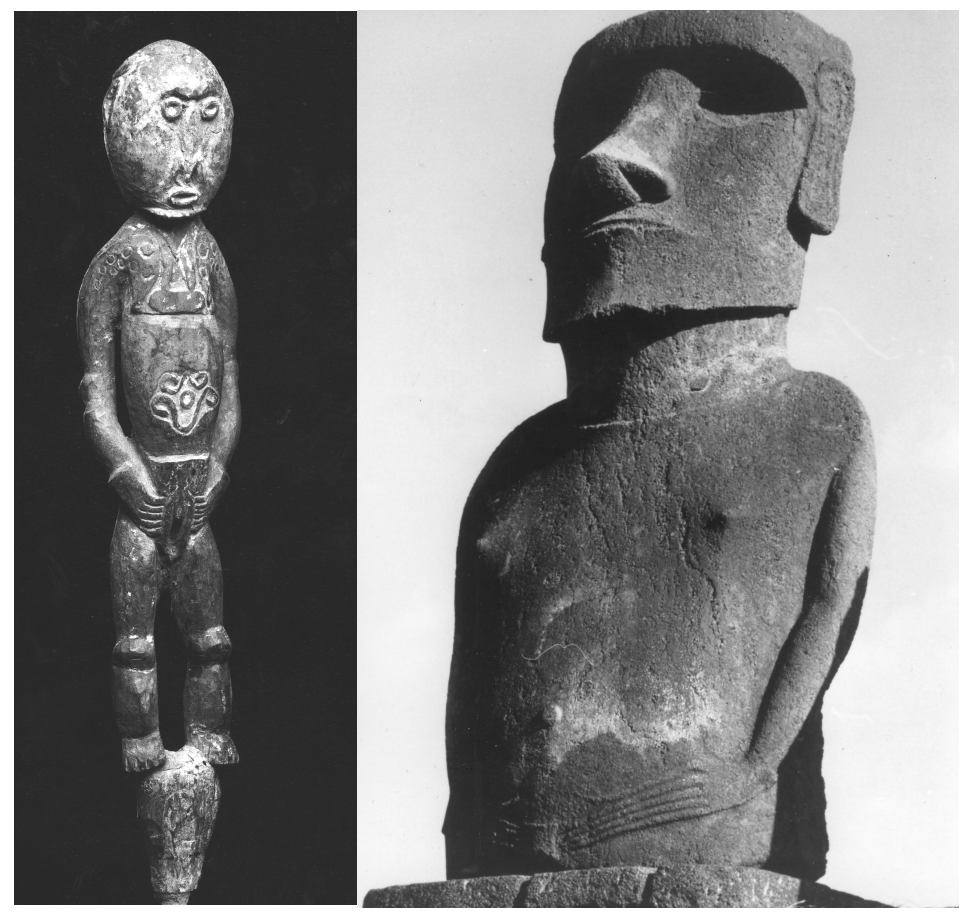

Figure 15. Female spirit figure of the Abelam. Maprik area, Papua New Guinea. (C) Museo delle Culture, Lugano. Collezione Brignoni,

Figure 16. Female colossal figure of the Naunau platform in Anakena, Easter Island. The long and expressive fingers intentionally hint to the genital region. Photo: Eibl-Eibesfeldt.

If the ritualization of behavior is defined by constancy of form and the enhancement of the signal function of a movement (Eibl-Eibesfeldt, 2004, p. 616f), the features are met in the high stylization and intensification of the gesture in discussion. Sometimes the phenomenon gets to a point where the gesture takes on a life of its own and even prevails over the organ it 
is hinting at. Then, the organ disappears behind the gesture, like in some stelae of Neolithic Upper Italy (see Fig. 17) or even in figures of Romanesque churches, like the ones at the entrance of St. Jakob in Regensburg, Germany (see Fig. 18). The gesture remains as a kind of substitute of the organ. Interestingly enough, the hinting hands are not restricted to female figures but appear as well in male examples. The hands seem to function as accentuating and hinting organs in an impressive human gesturing.
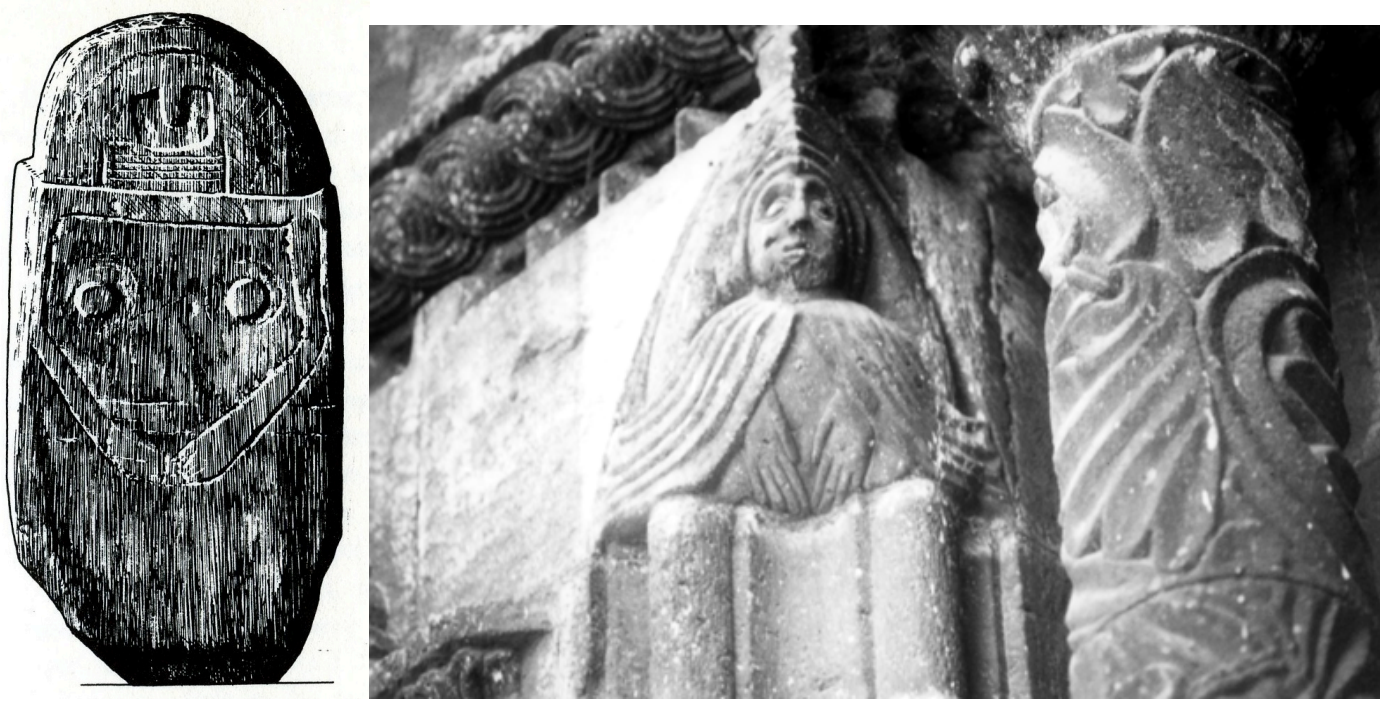

Figure 17. Neolithic stela from Pontevecchio (Northern Italy), ca. 4000 B.C. From Anati 1981, fig.53a.

Figure 18. Female figure from the Northern entrance of St. Jakob, Regensburg, Germany. $12^{\text {th }}$ century. Photo: Sütterlin.

\section{DISCUSSION}

Humans seem to communicate with the spiritual world in similar ways like with their conspecifics - by means of a repertoire of nonverbal expressions that is well-founded and successful during evolution. But unlike animals, humans do not rely on their own physical body to communicate. Instead they can produce figures that bear signals and behaviors to impress their fellow men. Humans create instruments of communication on many cultural levels. And an artifact may easily substitute a human being performing with endurance in the inclemencies of the weather.

In addition, art offers further possibilities for a cultural ritualization - by any sorts of signalistic exaggeration and expressive accumulation, and if these features are performed in a similar way cross-culturally, we may accept their similar rank of evaluation. This again would include a biological rudiment of interpretation or meaning. Moreover, frozen behaviors in 
art often present a definable context of use and application. This contributes to their interpretation as well on a behavioral level.

Similarities in art and perception do not meet in a shared environment, but in a similar way of the environments interpretation. A theoretical impact of studying artistic forms of ritualization for a general discussion of the gesture could be the insight into common concepts of "semantization" of the human and nonhuman environment. This allows for a comparison on common grounds. Art is not the first and only instrument for construing and evaluating reality, but, on a previous and more basic level, our perception as well. The analysis of nonverbal communication, expressive movements and ritualizations of behavior inform us about our responsiveness to symbolic transactions and performances. Signs and evidence of a symbolic language in the arts hit our immediate understanding. Therefore it should not be too amazing if artistic representation were to open up new insights into the function and meaning of human behaviors. The gesture of female sexual display in its archaic and cross-cultural embodiments, as presented here, can contribute to understanding the ethological importance, function and meaning of a mostly hidden and half forgotten female dominance gesture.

\section{REFERENCES}

Andersen, J. (1977). The Witch on the Wall. Medieval Erotic Sculpture in the British Isles. Copenhagen: Rosenkilde and Bagger.

Anati, E. (1981). Le Statue-Stele della Lunigiana. I testimoni dell'ultima rivoluzione culturale della preistoria. Milano: Jaca Books.

Charrière, G. (1970). La signification des représentations érotiques dans l'art des sauvages et préhistoriques. Paris: Maisonneuve et Larose

Conteneau, G. (1914). La Déesse Nue Babylonienne. Paris: Geuthner.

Deonna, W. (1917) Talismans de guerre dans l'ancienne Genève. Schweizerisches Archiv für Volkskunde XXI, 97-98.

Devereux, G. (1981). Baubo. Die mythische Vulva. Frankfurt: Syndikat.

Dissanayake, E. (1992). Homo Aestheticus. Where Art Comes From and Why. New York: The Free Press.

Dutton, D. (2009). The Art Instinct. Pleasure and Human Evolution. New York: Bloomsbury Press.

Eibl-Eibesfeldt, I. (1970). Männliche und weibliche Schutzamulette im modernen Japan. Homo 21, 175-188.

Eibl-Eibesfeldt, I. (1972). Die !Ko Buschmann-Gesellschaft. München: Piper.

Eibl-Eibesfeldt, I. (2004) $)^{5}$. Die Biologie menschlichen Verhaltens. Grundriss der Humanethologie. München: Piper. 
Sütterlin, Ch.: Universals in Ritualized Genital Display of Apotropaic Female Figures Human Ethology Bulletin - Proc. of the V. ISHE Summer Institute (2016): 30-46

Eibl-Eibesfeldt, I. \& Wickler, W. (1968). Die ethologische Deutung einiger Wächterfiguren auf Bali. Zeitschrift für Tierpsychologie 25 (6), 719-726.

Eibl-Eibesfeldt, I. \& Sütterlin, Ch. (1992). Im Banne der Angst. Zur Natur- und Kunstgeschichte menschlicher Abwehrsymbolik. München: Piper.

Eibl-Eibesfeldt, I. \& Sütterlin, Ch. (2008) $)^{2}$. Weltsprache Kunst. Zur Natur- und Kunstgeschichte bildlicher Kommunikation. Wien: Brandstätter.

Fraser, D. (1966). The Heraldic Woman: a Study in Diffusion. In D.Fraser (Ed.), The Many Faces of Primitive Art. New Jersey: Englewood \& Cliffs, 34-99.

Goldman, B. (1961). The Asiatic Ancestry of the Greek Gorgon. Berytus, 14: 1-23.

Goodman, J. (1996). Meet the Akha. Bangkok: White Lotus Ltd.,113-115.

Gsell, M. (2001). Die Bedeutung der Baubo. Zur Repräsentation des weiblichen Genitales. Frankfurt: Stroemfeld.

Hansmann, L \& Kriss-Rettenbeck, L. (1966). Amulett und Talismann. München: Callwey.

Hauschild, Th,. (1984) Abwehrmagie und Geschlechtssymbolik im Mittelmeerraum. Curare (Sonderband) 2, 205-222. DOI

Kirchhoff, H. (1984). Die „Kopffüssler“ von Priene, part II: Problematik der Fruchtbarkeitsidole. Sexualmedizin, 13, 227-230.

Koenig, O. (1975). Urmotiv Auge. Neuentdeckte Grundzüge menschlichen Verhaltens. München: Piper.

Kohl, J.G. (1843). Reisen in Irland, 1-2. Dresden, Leipzig: Arnoldische Buchhandlung.

Leuzinger, E. (1985). Kunst der Naturvölker. Propyläen Kunstgeschichte 22. Berlin: Propyläen.

Mellink, M. \& Filip, J. (1985). Frühe Stufen der Kunst. Propyläen Kunstgeschichte 14. Berlin: Propyläen.

Murray M.A. (1934). Female Fertility Figures. The Journal of the Royal Anthropological Institute of Great Britain and Ireland, 64, 93-100. DOI

Plinius Sec. G. (1983). Naturkunde, 26/27. (Translation R. König). München: Artemis. DOI

Ploog, D., Blitz, J. \& Ploog, F. (1963). Studies on social and sexual behavior oft the squirrel monkey (Saimiri sciureus). Folia Primatologica 1, 29-66. DOI

Przyluski, J. (1950). La Grand Déesse. Paris: Payot.

Qasim, E. (2009). Frauenstatuetten: Zwei Gesten als Teil der Darstellung. In K.Schmidt (Ed.) Erste Tempel - Frühe Siedlungen. Archae Nova. Oldenburg: Isensee.

Reinach, S. (1912). Cultes, Mythes et Religions. Paris: Leroux.

Reynolds, V. \& Reynolds, F. (1965). Chimpanzees of the Budongo forest. In I.De Vore (Ed.), Primate Behavior. New York: Thomson Publ.

Ross, A. (1973). The Divine Hag of the Pagan Celts. In Newall, V. (Ed.), The Witch Figure. London: Routledge, 139-164. 
Sütterlin, Ch.: Universals in Ritualized Genital Display of Apotropaic Female Figures

Human Ethology Bulletin - Proc. of the V. ISHE Summer Institute (2016): 30-46

Rowell T.E. (1963). Behavior and female reproductive cycles of Rhesus macaques. Journal of Reproductive Fertility, 6.,193-203. DOI

Sankalia, H.D. (1960). The Nude Goddess or „Shameless Woman“ in Western Asia, India, and South-Eastern Asia. Artibus Asiae XXIII, 111-123. DOI

Schefold, K. (1954). Zweit Tonstatuetten von Kreissenden in Privatbesitz. Jahrbuch des Deutschen archäologischen Instituts, 69, 217-223.

Schieffelin, E.L. \& Crittenden, R. (1991). Like People You See in a Dream. Stanford: University press.

Schmidt, K. (2013). Von Knochenmännern und anderen Gerippen: Zur Ikonographie halb- und vollskelettierter Tiere und Menschen in der prähistorischen Kunst. In S. Feldmann \& Th. Uthmeier (eds.) Gedankenschleifen. Gedenkschrift für Wolfgang Weißmüller. Erlanger Studien zur Prähistorischen Archäologie. Büchenbach: Dr. Faustus.

Sheridan, R. \& Ross, A. (1975). Grotesques and Gargoyles. Paganism in the Medieval Church. Boston: New York Graphic Society.

Striedter, K. (1984). Felsbilder der Sahara. München: Prestel.

Sütterlin, Ch. (1989). Universals in Apotropaic Symbolism: A Behavioral and Comparative Approach to Some Medieval Sculptures. Leonardo, 22 (1), 65-74. DOI

Sütterlin, Ch. (2000). Die Sirene als Bildmotiv zwischen Funktion und Dekoration. Mythenforschung als Bild- und Ideengeschichte. In: M. Liedtke (Ed.), Relikte. Der Mensch und seine Kultur. Graz: austria medien service.

Sütterlin, Ch. (2013). Early Face Representation as Proto- or Archetype of a Generalized Human Face Perception. In: K. Sachs-Hombach \& J. Schirra /(Ed.) Origins of Pictures. Chemnitz: Von Halem, 90-109.

Sütterlin, Ch., Schiefenhövel, W., Lehmann, Ch., Forster, J., Apfelauer, G. (2014). Art as Behaviour. An Ethological Approach to Visual and Verbal Art, Music and Architecture. Hanse Studien 10. Oldenburg: BIS

Vanggaard. Th. (1971). Phallos. Symbol und Kult in Europa. München: List.

Wickler, W. (1966). Ursprung und biologische Deutung des Genitalpräsentierens männlicher Primaten. Zeitschrift für Tierpsychologie 23, 422-437. DOI

Wickler, W. (1967). Socio-sexual Signals and their Intra-specific Imitation among Primates. In D.Morris (Ed.) Primate Ethology. London: Weidenfeld \& Nicholson, 69-147.

Willey, G.R. (1985). Das alte Amerika. Propyläen Kunstgeschichte 19. Berlin: Propyläen.

Young, G. (1974). The Hilltribes of Northern Thailand, Bangkok: Siam Society. 